Etihad: Journal of Islamic Banking and Finance

Vol. 1, No. 2 Juli-Desember: 115-131

\title{
FAKTOR-FAKTOR YANG MEMPENGARUHI MINAT BERINVESTASI SAHAM SYARIAH
}

\author{
Yusuf Satrio Ratmojoyo ${ }^{1 *}$, Trisiladi Supriyanto ${ }^{2}$, Siwi Nugraheni ${ }^{3}$ \\ 1,2,3 Universitas Pembangunan Veteran Jakarta, Indonesia \\ Email: yusuf.satrio@upnvj.ac.id, trisiladi.supriyanto@gmail.com, \\ siwinugraheni@upnvj.ac.id
}

\begin{abstract}
The purpose of this research to analyze the effect of financial literacy, risk, investment psychology, and social media on the investment interest of the people of Jakarta in Islamic stocks. The sample used in this study uses one hundred people who will represent the entire population. Data collection in this study was carried out using a questionnaire distributed by the purposive sampling technique. The statistical methods used are descriptive statistical analysis, classical assumptions, multiple linear regression, validity and reliability, and hypotheses using SPSS Statistics 23 application as a data processor. The results of this study are the influence of the independent variables simultaneously on the interest in investing in Islamic stocks. However, in a partial test, only financial literacy, risk, and investment psychology factors have a significant influence on interest in investing in Islamic stocks, while social media factors do not have a significant influence on interest in investing in Islamic stocks.
\end{abstract}

Keywords: Financial literacy; investment psychology; Islamic stocks; risk; social media.

\begin{abstract}
Abstrak: Tujuan penelitian ini untuk menganalisis pengaruh literasi keuangan, risiko, psikologi investasi, dan media sosial terhadap minat berinvestasi masyarakat Jakarta pada saham syariah. Sampel yang digunakan berjumlah seratus orang yang mewakili seluruh populasi. Pengumpulan data penelitian dilakukan dengan menggunakan kuesioner yang disebar dengan teknik purposive sampling. Metode statistik yang digunakan adalah analisis statistik deskriptif, asumsi klasik, regresi linier berganda, validitas dan reliabilitas, serta hipotesis dengan menggunakan alat bantu berupa aplikasi SPSS Statistics 23 sebagai pengolah data. Hasil penelitian menunjukkan adanya pengaruh variabel bebas secara bersamaan terhadap minat berinvestasi saham syariah. Akan tetapi pada pengujian secara parsial, hanya faktor literasi keuangan, risiko, dan psikologi investasi yang memiliki pengaruh signifikan terhadap minat berinvestasi saham syariah, sedangkan faktor media sosial tidak memiliki pengaruh yang signifikan terhadap minat berinvestasi saham syariah.
\end{abstract}

Keywords: media sosial; literasi keuangan; psikologi investasi; risiko; saham syariah. 
Etihad: Journal of Islamic Banking and Finance

Vol. 1, No. 2 Juli-Desember: 115-131

\section{PENDAHULUAN}

Kegiatan ekonomi adalah hal yang tidak lepas dari kehidupan bermasyarakat. Masyarakat diharuskan untuk dapat mengelola keuangannya agar segala sesuatu yang menjadi kebutuhannya dapat terpenuhi. Didapati banyak cara yang dapat dilakukan untuk memenuhi hajat, antara lain dengan berinvestasi. Investasi biasanya dipergunakan untuk pengembangan suatu usaha terbuka dengan maksud untuk memperoleh keuntungan di masa mendatang (Sudirman \& Alhudori, 2018). Berinvestasi merupakan salah satu cara yang sudah diajarkan dalam islam, karena hal tersebut tertulis pada QS Al-Hasyr tepatnya dalam ayat 18.

Indonesia belum terjun secara langsung untuk berinvestasi pada pasar modal. Berdasar data Kustodian Sentral Efek Indonesia (KSEI) pada akhir tahun 2020, jumlah investor pasar modal Indonesia hanya sebesar 3,88 juta atau naik sedikit dari awal tahun 2020 yang berjumlah 2,5 juta investor (KSEI, 2020) dengan investor saham sebesar 2 juta investor (Otoritas jasa keuangan, 2021). Jumlah investor demikian dikatakan sangat sedikit apabila dibandingkan dengan populasi masyarakat Indonesia yang menurut Badan Pusat Statistik (2020) berjumlah lebih dari 270 juta penduduk.

Gambar 1. Statistik Tingkat Literasi Keuangan Indonesia per Sektor

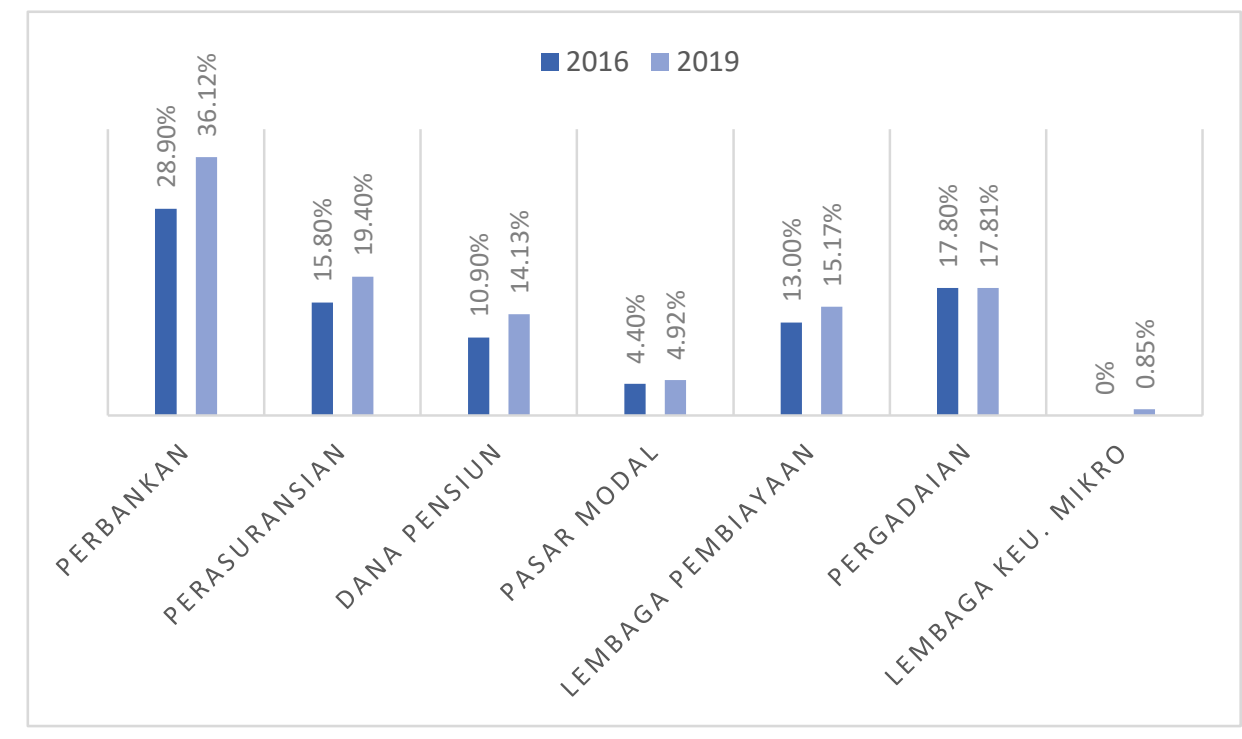

Minimnya literasi keuangan pada sektor pasar modal terbukti sejalan dengan tingkat literasi keuangan syariah. Menurut data yang tercatat pada Survei Nasional Literasi Keuangan (SNLK) 2019 OJK, indeks literasi keuangan syariah pada tahun 2019 sebesar 8,93 $\%$, dan hanya meningkat 8,1\% dibanding tahun 2018 (KNEKS, 2019). Hal demikian sejalan dengan minimnya jumlah investor pada saham syariah yang hanya sebesar 85 ribu investor (Herman, 2021). Adanya permasalahan tingkat literasi yang minim demikian menyebabkan beberapa investor hanya mengikuti tren pembelian investasi saham yang memiliki kenaikan tinggi seperti saham farmasi pada awal tahun 2021. Padahal dengan adanya globalisasi, masyarakat dimudahkan dengan internet dan media sosial untuk menunjang literasi 
Etihad: Journal of Islamic Banking and Finance

Vol. 1, No. 2 Juli-Desember: 115-131

keuangan guna mengetahui segala bentuk investasi seperti risiko dan psikologi. Hal demikian menjadi bersinggungan dengan observasi yang dilakukan Isticharoh \& Kardoyo (2020), bahwa teknologi media sosial dapat mempengaruhi minat investasi.

Seorang investor sepantasnya sudah mempelajari dan mengetahui banyak hal terkait investasi. Penelitian ini dilaksanakan agar pembaca khususnya investor yang hendak berpartisipasi investasi saham syariah dapat memahami aspek-aspek yang diperlukan sebelum investasi.

\section{TINJAUAN LITERATUR}

\section{Minat Berinvestasi}

Minat investasi merupakan suatu keinginan yang terdapat dalam diri seseorang untuk mulai mempelajari hal yang berhubungan dengan investasi hingga pada tahap melakukan paktiknya (Pajar \& Pustikaningsih, 2017). Dalam investasi, seorang akan berminat apabila didorong dengan faktor-faktor pendukung seperti pelatihan pasar modal dan return (Tandio \& Widanaputra, 2016). Pelatihan pasar modal adalah salah satu dari banyaknya program yang dijalankan oleh BEI yang bekerjasama dengan PT. Kustodian Sentral Efek Indonesia (KSEI), PT. Kliring Penjaminan Efek Indonesia (KPEI), dan perusahan sekuritas (Listyani, et al., 2019) Sedangkan return adalah hasil investasi yang diharapkan oleh investor dari perusahaan yang diinvestasikan (Abidin, 2017).

Didapati beberapa faktor yang dapat mempengaruhi minat seorang dalam berinvestasi, antara lain faktor psikologi. Menurut (Tanusdjaja, 2018), faktor psikologi dapat mempengaruhi seorang investor dalam menentukan hasil yang akan dicapai. Selain beberapa faktor tersebut, menurut (Salisa, 2020) minat seorang dalam berinvestasi juga dapat dipengaruhi oleh persepsi kendali perilaku, literasi keuangan, dan persepsi risiko.

Mendalami instrumen investasi merupakan salah satu ciri seorang yang memiliki minat berinvestasi (Listyani, et al, 2019). Hal demikian perlu dilakukan karena seorang investor harus memahami analisis, profitabilitas, hingga risiko yang kemungkinan akan diterima pada instrumen yang dipilih.

\section{Saham Syariah}

Saham syariah menurut Rodoni \& Fathoni (2019) adalah saham perusahaan publik yang dalam operasionalnya memenuhi prinsip syariah. Di Indonesia, ulama-ulama yang terkordinasi dengan DSN-MUI memiliki kewenangan membuat fatwa lembaga ekonomi dan keuangan (Saputra, 2016). Setiap saham syariah yang ada pada pasar modal syariah, akan masuk kedalam catatan DES (Daftar Efek Syariah) dan dikeluarkan oleh OJK secara periodik setiap bulan Mei dan November. Hingga saat ini proses seleksi saham syariah oleh OJK terikat dengan beberapa kriteria sebagaimana berikut (IDX, 2018):

1. Kegiatas perusahaan tidak meliputi:

a. Maysir (perjudian);

b. Melakukan perdagangan tidak sesuai dengan syariah; 
Etihad: Journal of Islamic Banking and Finance

Vol. 1, No. 2 Juli-Desember: 115-131

c. Mengandung riba;

d. Transaksi jual dan beli suatu risiko dengan unsur gharar yang didalamnya dan/atau maysir (perjudian), dapat dicontohkan seperti asuransi yang bersifat konvensional;

e. Melakukan kegiatan produksi, distribusi, menjual, dan/atau menyediakan hal yang haram dan mengandung mudarat (yang dalam penggunaannya dapat merusak moral) atau keburukan

f. Bertransaksi yang didalamnya terdapat suap (unsur risywah);

2. Perusahaan yang rasio keuangannya memenuhi ketentuan sebagai berikut:

a. Perbandingan utang total tidak lebih dari $45 \%$ bila dibandingkan dengan total aset; atau

b. Total pendapatan yang terdapat riba tidak lebih dari $10 \%$ bila dibandingkan dengan total revenue (pendapatan usaha).

Dengan adanya kriteria dan ketentuan saham syariah yang membuatnya berbeda dengan saham konvensional. Kesimpulannya adalah adanya perbedaan antara keduanya terletak pada jenis usaha perusahaan dan mekanisme perusahaan yang prosesnya terbebas dari unsur riba dan spekulasi (Rodoni \& Fathoni, 2019 hlm. 58).

\section{Literasi Keuangan}

Literasi keuangan adalah suatu kemampuan seorang untuk mengolah keuangan dengan tujuan meningkatkan kesejahteraan. Hal demikian terdorong atas faktor diri sendiri seperti psikologi, kemampuan kognitif, keadaan eksternal, keadaan sosial, dan ekonomi (Nasution \& Fatira, 2019). Literasi keuangan merupakan hal yang penting karena pada dasarnya segala keputusan keuangan membutuhkan pengetahuan yang cukup agar dapat mengelola keuangan secara mumpuni. Minimnya tingkat literasi keuangan dapat membuat seorang berpikir buruk tentang keuangan, sehingga berdampak buruk atas pengambilan keputusan (Janor et al, 2016). Menurut Zulaihati, et al, (2020), literasi keuangan dapat mempengaruhi perilaku menabung, perilaku berbelanja, dan perencanaan jangka panjang ataupun pendek.

Secara umum, literasi keuangan syariah memiliki kesamaan terminologi dan tujuannya. Dalam pengertiannya menurut Nurrohmah \& Purbayati (2020), literasi keuangan ialah suatu pengetahuan atau pemahaman tentang keuangan syariah. Sedangkan tujuan literasi keuangan adalah meningkatkan pengetahuan masyarakat untuk dapat mengubah perilaku dalam mengelola finansial secara lebih baik, halal, dan memilah ajakan investasi yang bodong (Nasution \& Fatira, 2019).

\section{Risiko}

Risiko merupakan perihal yang berkaitan dengan penyimpangan dari hasil yang diperoleh secara ekspektasi (Hadinata, 2018). Risiko datang bersamaan dengan keuntungan yang diinginkan selama berinvestasi. Maka dalam berinvestasi, seorang harus memahami apa yang sedang dilakukannya sebagai bentuk antisipasi meminimalisir risiko diterimanya 
Etihad: Journal of Islamic Banking and Finance

Vol. 1, No. 2 Juli-Desember: 115-131

(Saraswati \& Wirakusuma, 2018). Secara kuantitatif, pengukuran risiko dapat dilakukan dengan tersedianya informasi, atau dalam istilah fikih untuk mengindari praktik tadlis dan gharar. Gharar adalah suatu kondisi dimana minimnya pengetahuan yang dialami oleh dua pihak, sedangkan tadlis hanya sepihak (Malik, 2017). Menurut Pramana \& Badera (2017) didapati dua faktor risiko yang mempengaruhi minat investasi, yaitu tingkat suku bunga dan struktur modal suatu perusahaan.

1. Tingkat suku bunga, adalah faktor yang dapat mempengaruhi investor dalam mengambil keputusan investasi, karena semakin tinggi tingkat suku bunga dapat menyebabkan investor lebih tertarik menempatkan dananya ke deposito (Widyastuti \& Andamari, 2013).

2. Struktur modal, merupakan faktor yang memiliki hubungan negatif dengan keuntungan, semakin tinggi keuntungan, maka tingkat hutang perusahaan akan semakin rendah. (Watiningsih, 2018). Keuntungan perusahaan nantinya dapat memberi nilai objektif atas nilai berinvestasi pada suatu perusahaan. Setiap investor harus memperhatikan informasi-informasi yang berkaitan dengan perusahaan yang diinvestasikan (Oktrima, 2017).

Seorang investor yang berpengalaman akan memiliki kecenderungan melakukan investasi lagi. la akan memilih jenis investasi yang memilki risiko lebih tinggi daripada sebelumnya dengan harapan return yang diterima juga lebih tinggi (Putra, et al., 2016).

\section{Psikologi Investasi}

Psikologi investasi merupakan karakter seseorang dalam berinvestasi yang dibentuk oleh adanya beberapa faktor, antara lain faktor keamanan, kenyamanan, pemikiran bias, keberanian akan risiko, kepercayaan atas diri sendiri, interaksi dengan sosial dan emosi, serta penilaian bias (Azis, et al., 2015). Sebelum berinvestasi, didapati beberapa persiapan yang harus dilakukan antara lain; mengevaluasi kemampuan diri, menentukan tujuan dan proporsi investasi, serta mendalami investasi (Lan, et al 2018). Dari sisi psikologi, menurut (Susanti et al., 2018) menyebut beberapa faktor yang dapat mempengaruhi minat seseorang; motivasi, perhatian, pengetahuan, keyakinan, dan sikap.

Menurut (A. H. Nugroho, 2019) setiap investor memiliki tipikal psikologi yang berbeda. Hal demikian menjadikan setiap investor dapat melakukan tindakan tertentu pada suatu keadaan. Setiap tindakan yang dilakukan orang dapat mempengaruhi dan menyaring setiap informasi, kemudian mengelolanya sehingga dapat mengambil keputusan yang dapat berdampak atas portofolionya.

\section{Media Sosial}

Media sosial adalah sebuah wadah daring, yang penggunanya dapat serta untuk berpartisipasi, berbagi, dan saling menciptakan isi dari media yang dipilih (Ainiyah, 2018). Media sosial dapat dikatakan sebagai alat promosi yang efektif, karena lebih menjangkau banyak orang (Bate'e, 2019). Media sosial dapat membentuk perilaku keuangan seseorang. 
Etihad: Journal of Islamic Banking and Finance

Vol. 1, No. 2 Juli-Desember: 115-131

Hal demikian karena adanya berita atau informasi yang dipublikasikan oleh media yang menggambarkan kondisi ekonomi dan bisnis dari suatu negara (Riski \& Sulistianingsih, 2020).

Minat seseorang dalam berinvestasi juga dapat dilihat dari beberapa hal, antara lain; intensitas menggunakan media sosial, pemanfaatan dalam mencari informasi investasi di media sosial, serta keefektifan menggunakan media sosial (Isticharoh \& Kardoyo, 2020).

\section{Hipotesis}

$\mathbf{H}_{1}$ : Literasi Keuangan mempengaruhi secara parsial terhadap minat berinvestasi pada saham syariah.

$\mathbf{H}_{\mathbf{2}}$ : Risiko mempengaruhi secara parsial terhadap minat berinvestasi pada saham syariah.

$\mathbf{H}_{3}$ : Psikologi Investasi mempengaruhi secara parsial terhadap minat berinvestasi pada saham syariah.

$\mathbf{H}_{\mathbf{4}}$ : Media Sosial mempengaruhi secara parsial terhadap minat berinvestasi pada saham syariah.

$\mathbf{H}_{5}$ : Literasi keuangan, risiko, psikologi investasi, dan media sosial mempengaruhi secara terhadap minat berinvestasi pada saham syariah.

\section{METODE PENELITIAN}

Penelitian ini merupakan observasi bersifat kuantitatif, karena data yang diperoleh akan dianalisis menggunakan statistik yang kemudian hasilnya dapat berupa angka dan dijelaskan menggunakan deskripsi.

\section{Pengukuran Variabel}

Dalam penelitian ini, variabel yang tersedia diukur dengan menggunakan indikator penelitian yang diambil dari setiap variabel yang adan. Langkah selanjutnya disebar kepada responden dengan menggunakan kuesioner. Populasi yang digunakan dalam observasi ini mencakup daerah Jakarta; Jakarta Barat, Jakarta Timur, Jakarta Utara, Jakarta Selatan, dan Jakarta Pusat dengan kriteria responden minimal berusia 17 tahun yang bertempat tinggal di Jakarta. Responden yang dipilih memiliki nomor SID (Single Investor Identification), dan mengetahui tentang saham syariah. Teknik penelitian ini menggunakan penyebaran kuesioner dengan teknik purposive sampling yang kemudian diukur dengan menggunakan skala likert. Adapun indikatornya sebagaimana berikut:

Tabel 1. Pengukuran Variabel

\begin{tabular}{lll}
\hline \multicolumn{1}{c}{ Variabel } & \multicolumn{2}{c}{ Indikator } \\
\hline Minat berinvestasi & pada & - Pelatihan pasar modal \\
saham syariah (Y) & - Kemungkinan return \\
& (Tandio \& Widanaputra, 2016) \\
Literasi Keuangan (X1) & - Pengetahuan lembaga dari jasa keuangan \\
& - Keyakinan lembaga dari jasa keuangan \\
& - Keterampilan penggunaan produk jasa
\end{tabular}


Etihad: Journal of Islamic Banking and Finance

Vol. 1, No. 2 Juli-Desember: 115-131

\begin{tabular}{ll}
\hline \multicolumn{1}{c}{ Variabel } & \multicolumn{1}{c}{ Indikator } \\
\hline \multirow{2}{*}{ Risiko (X2) } & (Otoritas jasa keuangan, 2013) \\
& - Tingkat suku bunga \\
& (Pramana \& Badera, 2017) \\
Psikologi Investasi (X3) & - Motivasi \\
& - Perhatian \\
& (Susanti et al., 2018) \\
Media Sosial (X4) & - Jangka waktu penggunaan media sosial \\
& - Pemakaian media sosial \\
& - Efektivitas penggunaan media sosial \\
& (Isticharoh \& Kardoyo, 2020) \\
&
\end{tabular}

Sumber: data diolah (2021)

\section{Teknik Analisis Data}

\section{Analisis Statistik Deskriptif}

Penelitian ini menggunakan teknik analisis statistik deskriptif kuantitatif. Adapun fungsi teknik tersebut untuk menganalisis dan mengelola suatu angka atau data agar dapat menghasilkan penjelasan secara jelas, teratur mengenai suatu peristiwa, keadaan atau gejala tertentu (Sholikhah, 2016). Adapun pada pengujian ini menggunakan teknik skoring dengan skala 1 hingga 4:

Tabel 2. Teknik Skoring

\begin{tabular}{ccc}
\hline Pernyataan & Pngertian & Skor \\
\hline STS & Sangat Tidak Setuju & 1 \\
\hline TS & Tidak Setuju & 2 \\
\hline S & Setuju & 3 \\
\hline SS & Sangat Setuju & 4 \\
\hline \multicolumn{2}{l}{ Sumber: data diolah (2021) }
\end{tabular}

Mengacu pada tabel 2, maka didapati hasil penyebaran kuesioner yang diperlukan pengujian statistik deskriptif guna mengetahui nilai rata-rata setiap variabel. Selanjutnya, nilai-nilai demikian disajikan dalam bentuk tabel dengan menggunakan rumus sebagai berikut (Sudjana, 2002):

$$
P=\frac{\text { Rentang }}{\text { Jumlah Kelas }}
$$

Keterangan:

$P$

: Panjang interval

Rentang

: Data terbesar-terkecil

Banyak Kelas

: (4) 
Etihad: Journal of Islamic Banking and Finance

Vol. 1, No. 2 Juli-Desember: 115-131

Sehingga dalam kajian ini jarak interval yang digunakan adalah sebagai berikut:

$$
\begin{aligned}
& P=\frac{4-1}{4} \\
& P=\frac{3}{4} \\
& \mathrm{P}=0,75
\end{aligned}
$$

Berdasar dengan hasil tersebut, maka dapat ditentukan bahwa penilaian ratarata berdasarkan interval kelas tersebut adalah sebagai berikut:

Tabel 3. Tabel kelas interval

\begin{tabular}{cc}
\hline Skor & Kategori \\
\hline $1-1,75$ & Sangat Tidak Setuju \\
$1,76-2,5$ & Tidak Setuju \\
$2,6-3,25$ & Setuju \\
$3,26-4$ & Sangat Setuju \\
\hline \multicolumn{2}{l}{ Sumber: data diolah (2021) }
\end{tabular}

\section{HASIL DAN PEMBAHASAN}

\section{Analisis Statistik Deskriptif}

Dengan menggambarkan indikator yang ada pada setiap variabel, maka diharapkan dapat memberikan penjelasan tanggapan responden di setiap variabel. Hasil pengujian analisis statistik deskriptif penelitian ini sebagaimana berikut:

Tabel 4. Hasil Analisis Statistik Deskriptif

\begin{tabular}{ccccc}
\hline Variabel & N & Minimal & Maksimal & Rata-rata \\
\hline Minat Investasi & 100 & 1 & 4 & 3,26 \\
Literasi Keuangan & 100 & 1 & 4 & 2,80 \\
Risiko & 100 & 1 & 4 & 2,95 \\
Psikologi Investasi & 100 & 1 & 4 & 2,93 \\
Media Sosial & 100 & 1 & 4 & 3,08 \\
\hline
\end{tabular}

Sumber: data diolah (2021)

Tabel 4 menunjukan tanggapan responden terhadap variable minat berinvestasi pada saham syariah yang memiliki rata-rata sebesar 3,26. Hal demikian menunjukan bahwa mayoritas responden setuju dan berminat untuk investasi saham syariah. Kemudian pada variabel literasi keuangan menunjukan nilai 2,80 yang artinya mayoritas responden setuju bahwa literasi keuangan dapat mempengaruhi minat berinvestasi saham syariah. Setelah itu, variabel risiko menunjukan nilai 2,95 artinya kebanyakan responden setuju bahwa variabel risiko berpengaruh atas minat berinvestasi saham syariah. Pada variabel psikologi investasi, nilai rata-rata menunjukan 2,93 artinya mayoritas responden perlu mempertimbangkan faktor psikologi investasi sebelum minat 
Etihad: Journal of Islamic Banking and Finance

Vol. 1, No. 2 Juli-Desember: 115-131

berinvestasi saham syariah. Terakhir adalah variabel media sosial yang menujukan nilai rata-rata 3,08 yang artinya kebanyakan responden setuju jika media sosial mempengaruhi minat dalam berinvesatsi saham syariah.

\section{Uji Hipotesis}

\section{a. Uji Parsial (Uji T)}

Tabel 5. Uji Parsial (T)

\begin{tabular}{ccc}
\hline Model & t & Sig. \\
\hline Literasi Keuangan & 2,204 & 0,030 \\
Risiko & 3,320 & 0,001 \\
Psikologi Investasi & 2,498 & 0,014 \\
Media Sosial & 1,200 & 0,233 \\
\hline \multicolumn{2}{l}{ Sumber: data diolah (2021) }
\end{tabular}

Tabel 5 menunjukan pemerolehan nilai probabilitas alpha variabel literasi keuangan $(0,030<0,05) \& t$ hitung sebesar $(2,204<1,98)$, risiko $(0,001<0,05) \& t$ hitung sebesar $(3,320>1,98)$, psikologi investasi $(0,014>0,05) \& t$ hitung sebesar $(2,498>1,98)$ dan media sosial $(0,233>0,05) \& t$ hitung sebesar $(1,200>1,98)$. Sehingga dapat disimpulkan bahwa literasi keuangan (X1), risiko (X2), dan psikologi investasi (X3) memiliki pengaruh terhadap minat berinvestasi saham syariah $(\mathrm{Y})$ secara parsial, sedangkan pada variabel media sosial (X4) tidak berpengaruh terhadap minat berinvestasi saham syariah $(\mathrm{Y})$.

b. Uji Simultan (Uji F)

Tabel 6. Uji Simultan (F)

\begin{tabular}{ccc}
\hline Model & F Hitung & Sign. \\
\hline Regression & 22,057 & $0,000^{b}$ \\
\hline & Sumber: data diolah (2021)
\end{tabular}

Tabel 6 memperoleh nilai f hitung 22,057 dan nilai sig. 0,000, sehingga dapat disimpulkan dari data tersebut bahwa nilai $f$ hitung $>f$ tabel $(2,68)$ dan nilai signifikansi $(0,00<0,05)$. Setiap variabel independen memiliki pengaruh terhadap variabel dependen secara simultan atau dapat dikatakan H5 dapat diterima dan terdapat pengaruh antara literasi keuangan (X1), risiko (X2), psikologi investor (X3), dan media sosial (X4) secara bersamaan terhadap minat berivestasi saham syariah.

\section{c. Uji Koefisien Determinasi $\left(\mathbf{R}^{2}\right)$}

Tabel 7. Uji Koefisien Determinasi

\begin{tabular}{cccc}
\hline Model & $\mathbf{R}$ & $\mathbf{R}^{\mathbf{2}}$ & Adj. $\mathbf{R}^{\mathbf{2}}$ \\
\hline 1 & 0,694 & 0,482 & 0,460 \\
\hline
\end{tabular}


Etihad: Journal of Islamic Banking and Finance

Vol. 1, No. 2 Juli-Desember: 115-131

Sumber: data diolah (2021)

Tabel 7 menunjukan nilai R-Square sebesar 0,482. Dengan demikian dapat disimpulkan bahwa variabel literasi keuangan (X1), risiko (X2), psikologi investasi (X3), dan media sosial (X4) mempengaruhi variable minat berinvestasi saham syariah (Y) sebesar 48,2\%. Sedangkan sebesar $51,8 \%$ sisanya dipengaruhi oleh variabel yang tidak diteliti pada penelitian ini.

\section{d. Regresi Liniear Berganda}

Tabel 8. Uji Regresi Linear Berganda

\begin{tabular}{cccc} 
Model & Unstandardized Coefficients & $\begin{array}{c}\text { Standardized } \\
\text { Coefficients } \\
\text { Beta }\end{array}$ \\
\hline C & 6,520 & Std Error & 1,122 \\
Literasi Keuagan & 0,134 & 0,061 & 0,240 \\
Risiko & 0,303 & 0,091 & 0,299 \\
Psikologi Investasi & 0,231 & 0,092 & 0,213 \\
Media Sosial & 0,102 & 0,085 & 0,129 \\
\hline Sumber: data diolah (2021) & &
\end{tabular}

Sumber: data diolah (2021)

Dari tabel 11 dapat dibentuk persamaan regresi linier berganda, persamaan tersebut yaitu:

$\mathrm{Y}=\mathrm{a}-\mathrm{b} 1 \mathrm{X} 1+\mathrm{b} 2 \mathrm{X} 2+\mathrm{b} 3 \mathrm{X} 3+\mathrm{b} 4 \times 4+\mathrm{e}$

$Y=6,520+0,134 X 1+0,303 \times 2+0,231 X 3+0,102 X 4+e$

a : Konstanta

b : Koeisien Beta

X1 : Literasi Keuangan

$\mathrm{X} 2$ : Risiko

X3 : Psikologi Investasi

X4: Media Sosial

Nilai konstanta sebesar 6,520 mengartikan bahwa rata-rata besar minat investasi saham syariah di kota Jakarta sebesar 6,52 satuan kepuasan. Konstanta dalam hasil tersebut bernilai positif, artinya ada hubungan yang positif dengan variabel minat investasi.

Nilai koefisien regresi (b1) pada variable X1 sebesar 0,134 yang mengartikan jika setiap penambahan nilai literasi keuangan sebesar 1 satuan, maka akan meningkatkan variabel minat investasi saham syariah di Jakarta sebesar 0,134. Konstanta tersebut bernilai positif, artinya pada variabel literasi keuangan dengan variabel minat investasi terdapat hubungan yang positif. 
Etihad: Journal of Islamic Banking and Finance

Vol. 1, No. 2 Juli-Desember: 115-131

Nilai koefisien regresi (b2) pada variable X2 adalah sebesar 0,303. Nilai ini mengartikan jika setiap penambahan nilai risiko sebesar 1 satuan akan meningkatkan variabel minat investasi saham syariah di Jakarta sebesar 0,303. Konstanta tersebut bernilai positif, artinya pada variabel risiko dengan variabel minat investasi terdapat hubungan yang positif.

Nilai koefisien regresi (b3) pada variable X3 adalah sebesar 0,231. Artinya jika setiap penambahan nilai psikologi investasi sebesar 1 satuan akan meningkatkan variabel minat investasi saham syariah di Jakarta sebesar 0,231. Konstanta tersebut bernilai positif, artinya pada variabel psikologi investasi dengan variabel minat investasi terdapat hubungan yang positif.

Nilai koefisien regresi (b4) pada variable X4 adalah sebesar 0,102. Artinya jika setiap penambahan nilai media sosial sebesar 1 satuan akan meningkatkan variabel minat investasi saham syariah di Jakarta sebesar 0,102. Konstanta tersebut bernilai positif, artinya pada variabel media sosial dengan variabel minat investasi terdapat hubungan yang positif.

\section{Pembahasan}

\section{Pengaruh Literasi Keuangan terhadap Minat Investasi}

Melalui hasil yang ada, dapat dikatakan bahwa variable literasi keuangan (X1) berpengaruh pada minat investasi saham syariah. Hal demikian dibuktikan dengan nilai $t$ hitung $>\mathrm{t}$ tabel $(2,204>1,985)$, dan nilai signifikansi $<$ alpha $(0,030<0,05)$, dengan kata lain $\mathrm{H} 1$ diterima. Artinya variable literasi keuangan berdampak signifikan secara parsial terhadap minat investasi saham syariah.

Sebelum menjadi, investor seyogyanya seorang belajar mengenai hal investasi, salah satunya adalah literasi keuangan yang dapat digunakan oleh setiap investor sebagai bekal dalam berinvestasi. Dengan literasi keuangan, maka dapat memudahkan seorang dalam mengambil keputusan yang baik dalam kegiatan investasi. Sehingga dapat dikatakan bahwa responden penelitian ini menggunakan literasi keuangan sebagai salah satu faktor yang berdampak terhadap minat melakukan investasi saham syariah. Hasil demikian memiliki kesamaan pada penelitian Pangestika \& Rusliati (2019) yang menyatakan bahwa literasi keuangan memiliki dampak terhadap minat berinvestasi. Tetapi terdapat perbedaan pada hasil penelitian Shulhan Fariqi (2020) dan Fatimah (2020) yang dalam penelitiannya menjelaskan literasi keuangan tidak berdampak terhadap minat berinvestasi.

\section{Pengaruh Risiko terhadap Minat Investasi}

Melalui hasil penelitian yang ada, maka dapat dikatakan bahwa variable risiko (X2) berpengaruh terhadap minat investasi saham syariah. Hal demikian dibuktikan dengan nilai t hitung $>\mathrm{t}$ tabel $(3,320>1,985)$, dan signifikansi $<$ alpha $(0,001<0,05)$, dengan kata lain $\mathrm{H} 2$ diterima, artinya variabel risiko berdampak signifikan secara parsial terhadap minat investasi saham syariah. 
Etihad: Journal of Islamic Banking and Finance

Vol. 1, No. 2 Juli-Desember: 115-131

Dalam instrumen investasi, risiko yang ada memiliki tingkat yang heterogen. Maka dari itu, setiap investor harus paham atas risiko yang akan diterima agar dapat mengantisipasi dan meminimalisir risiko tersebut. Dari hasil yang ada, dapat disimpulkan bahwa responden penelitian mempertimbangkan risiko sebelum berminat untuk investasi saham syariah. Hal demikian memiliki kesamaan hasil dengan penelitian Malik (2017), yang menyatakan bahwa risiko memiliki pengaruh pada minat dalam berinvestasi. Akan tetapi hasil yang ada berbeda dengan penelitian Trenggana \& Kuswardhana (2017) yang menyatakan bahwa risiko tidak memiliki pengaruh terhadap minat berinvestasi.

\section{Pengaruh Psikologi Investasi terhadap Minat Investasi}

Melalui hasil penelitian yang ada, dapat dikatakan bahwa variable psikologi investasi (X3) berdampak terhadap minat investasi saham syariah. Demikian dibuktikan dengan $t$ hitung $>t$ tabel $(2,498>1,985)$, dan signifikansi $<$ alpha $(0,014<0,05)$, artinya H3 diterima, psikologi investasi berdampak signifikan secara parsial terhadap minat berinvestasi saham syariah.

Dalam investasi yang berisiko tinggi, sudah sewajarnya seorang berbekal psikologi yang baik, karena psikologi dapat berdampak pada keputusan yang akan dipilih. Pada kegiatan investasi, setiap tindakan harus berdasarkan psikologi yang baik agar tidak meremehkan risiko. Berdasarkan hasil pada penelitian ini, maka dapat dikatakan bahwa responden perlu mempertimbangkan aspek psikologi dalam berinvestasi, sebelum terjun untuk berpartisipasi pada saham syariah. Hasil penelitian mmenjelaskan hasil yang serupa dengan penelitian Susanti et al., (2018) yang menyatakan bahwa adanya pengaruh psikologi terhadap minat berinvestasi, serta penelitian Sarwar \& Afaf (2016) yang menyatakan bahwa adanya dampak psikologi terhadap keputusan berinvestasi

\section{Pengaruh Media Sosial terhadap Minat Investasi}

Melalui hasil penelitian yang ada, dapat dikatakan bahwa variabel media sosial (X4) berpengaruh terhadap minat investasi saham syariah.Hal tersebut dibuktikan dengan t hitung yang lebih kecil bila dibandingkan dengan t tabel $(1,200<1,985)$, selain itu signifikansi yang ada lebih besar bila dibandingkan dengan alpha $(0,233>0,05)$, dengan kata lain H4 ditolak, artinya variabel media sosial tidak berdampak signifikan secara parsial terhadap minat investasi saham syariah.

Dalam mencari informasi di media sosial, seorang tidak hanya menemukan informasi berisi sentimen positif, akan tetapi juga menemukan sentiment negatif. Dengan adanya dua kemungkinan tersebut, maka dapat mempengaruhi minat masyarakat dalam melakukan investasi instrumen saham. Hasil penelitian ini sesuai dengan penelitian Junifa (2019) yang menyatakan bahwa variabel media sosial tidak berpengaruh terhadap minat investasi saham syariah. Akan tetapi hasil pada penelitian ini tidak sesuai dengan penelitian yang dilakukan oleh Isticharoh dan Kardoyo (2020) yang menyatakan bahwa adanya pengaruh dari teknologi media sosial terhadap minat berinvestasi. Begitu juga 
Etihad: Journal of Islamic Banking and Finance

Vol. 1, No. 2 Juli-Desember: 115-131

penelitian Fikri (2020) yang menyatakan bahwa variable media sosial berdampak terhadap pasar modal dalam mempromosikan instrumen kepada investor.

5. Pengaruh Literasi Keuangan, Risiko, Psikologi Investasi, dan Media Sosial terhadap Minat Investasi

Melalui hasil penelitian yang ada, dapat dijelaskan bahwa variable literasi keuangan, risiko, psikologi investasi, dan media sosial dapat mempengaruhi minat berinvestasi saham syariah secara bersamaan. Hal demikian dapat dibuktikan dari uji $f$ dengan hasil $f$ hitung $>f$ tabel $(22,057>2,47)$. Selain itu nilai signifikansi $<$ alpha $(0,000<$ $0,05)$. Dari pembuktian demikian maka disimpulkan jika variable literasi keuangan, risiko, psikologi investasi dan media sosial berdampak signifikan secara bersamaan terhadap minat investasi saham syariah di Jakarta. Besaran pengaruh variabel demikian dapat dilihat berdasarkan nilai $\mathrm{R}^{2}$ sebesar $48,2 \%$, jadi variabel independen yang ada dapat menjelaskan sebanyak $48,2 \%$ dari variabel dependen.

\section{KESIMPULAN}

Berdasarkan hasil uji t dalam penelitian, maka variabel Media Sosial (X4) tidak berdampak terhadap minat berinvestasi saham syariah di Jakarta. Hal demikian dibuktikan dengan pengujian simultan, sehingga mengartikan bahwa investor membutuhkan sentimen yang baik sebelum memutuskan untuk berinvestasi saham syariah. Hasil penelitian pada variabel Literasi Keuangan (X1), Risiko (X2), dan Psikologi Investasi (X3) berdampak signifikan terhadap minat berinvestasi saham syariah di Jakarta.

Dengan adanya penelitian ini diharapkan dapat menjadi manfaat bagi masyarakat mengenai faktor yang dapat mempengaruhi minat berinvestasi saham syariah. Selain itu, diharapkan juga bagi pemerintah sebagai regulator untuk dapat membuat kebijakankebijakan baru yang dapat meningkatkan pemahaman masyarakat terutama terkait pasar modal, sehingga dapat menambah potensi jumlah investor di Indonesia. Namun adanya regulasi yang baik juga harus didorong dengan struktur modal yang baik dari perusahaan, agar dapat menarik investor lebih banyak di suatu perusahaan.

\section{REFERENSI}

Abidin, Z. (2017). Determinan Return Saham dan Implikasinya terhadap Nilai Perusahaan. Sekuritas, 1(2581), 18-33.

Ainiyah, N. (2018). Remaja Millenial dan Media Sosial: Media Sosial Sebagai Media Informasi Pendidikan Bagi Remaja Millenial. Jurnal Pendidikan Islam Indonesia, 2(2), 222.

Amir, M. T. (2015). Merancang Kuesioner (1st ed.). Jakarta: Kencana.

Azis, M., Mintarti, S., \& Nadir, M. (2015). Manajemen Investasi Fundamental, Teknikal, Perilaku Investor, dan Return Saham (1st ed.). Yogyakarta: Deepublish Publisher. 
Etihad: Journal of Islamic Banking and Finance

Vol. 1, No. 2 Juli-Desember: 115-131

Badan Pusat Statistik. (2020). Jumlah dan Distribusi Penduduk. Retrieved February 26, 2021, from https://sensus.bps.go.id/main/index/sp2020

Bate'e, M. M. (2019). Pengaruh Media Sosial Terhadap Keputusan Pembelian Di Toko Kaos Nias Gunungsitoli. JESYA, 2(2), 313-324.

Fatimah. (2020). Peran Pengetahuan Investasi dan Literasi Keuangan dalam Memediasi Pengaruh Edukasi Pasar Modal terhadap Minat Investasi Mahasiswa Fakultas Ekonomi Universitas Negeri Semarang. Universitas Negeri Semarang.

Ghozali, I. (2011). Aplikasi Analisis Multivariate Dengan Program SPSS. Semarang: Universitas Diponegoro.

Hadinata, S. (2018). Tingkat Pengembalian (Return), Risiko, dan Koefisien Variasi pada Saham Syariah dan Saham Nonsyariah. AKTSAR, 1(2), 171-186.

Herman. (2021). Jumlah Saham Syariah Meningkat 33\% dalam Lima Tahun. Retrieved from https://investor.id/market-and-corporate/jumlah-saham-syariah-meningkat-33-dalamlima-tahun

IDX. (2018). Saham Syariah. Retrieved November 21, 2020, from https://www.idx.co.id/idxsyariah/produk-syariah/

Isticharoh, \& Kardoyo. (2020). Minat Investasi Diprediksi Dari Motivasi Diri, Pengetahuan Investasi, dan Teknologi Media Sosial. Economic Education Analysis Journal, 9(3), 904.

Janor, H., Yakob, R., Hashim, N. A., Zanariah, \& Wel, C. A. C. (2016). Financial literacy and investment decisions in Malaysia and United Kingdom: A comparative analysis. Malaysian Journal of Society and Space, 2(2), 109.

Jaya, I. M. L. M. (2020). Metode Penelitian Kuantitatif dan Kualitatif. (F. Husaini, Ed.). Yogyakarta: Quadrant.

Junifa. (2019). Analisis Pengaruh Pemahaman Investor Tentang Teori Investasi, Sosialisasi Pasar Modal Syari'ah, Media Sosial, dan Pengetahuan Umum Terhadap Minat Berinvestasi Saham Syari'ah. Universitas Andalas. Retrieved

KNEKS. (2019). Literasi dan Edukasi Keuangan Syariah Akan di Dorong dengan Implementasi MEKSI. Retrieved October 28, 2020, from https://knks.go.id/berita/205/literasi-danedukasi-keuangan-syariah-akan-di-dorong-dengan-implementasi-meksi?category=1

KSEI. (2020). Peran Strategis dalam Meningkatkan Stabilitas Pasar Modal. KSEI News.

Lan, Q., Xiong, Q., He, L., \& Ma, C. (2018). Individual investment decision behaviors based on demographic characteristics: Case from China. PloS One, 13(8), 4.

Listyani, T. T., Rois, M., \& Prihati, S. (2019). Analisis Pengaruh Pengetahuan Investasi, Pelatihan Pasar Modal, Modal Investasi Minimal dan Persepsi Risiko terhadap Minat 
Etihad: Journal of Islamic Banking and Finance

Vol. 1, No. 2 Juli-Desember: 115-131

Investasi Mahasiswa di Pasar Modal. Aktual Akuntansi Keuangan Bisnis Terapan, 2(1), 49-70.

Malik, A. D. (2017a). Analisa Faktor - Faktor Yang Mempengaruhi Minat Masyarakat Berinvestasi Di Pasar Modal Syariah Melalui Bursa Galeri Investasi Uisi. Jurnal Ekonomi Dan Bisnis Islam (Journal of Islamic Economics and Business)2, 3(1), 71.

Malik, A. D. (2017b). Analisa Faktor - Faktor Yang Mempengaruhi Minat Masyarakat Berinvestasi Di Pasar Modal Syariah Melalui Bursa Galeri Investasi Uisi. Jurnal Ekonomi Dan Bisnis Islam (Journal of Islamic Economics and Business)2, 3(1), 73.

Meidiawati, K. (2016). Pengaruh Size, Growth, Profitabilitas, Struktur Modal, Kebijakan Devident terhadap Nilai Perusahaan. Jurnal IImu Dan Riset Akuntansi, 5(2), 11.

Nasution, A. W., \& Fatira, M. (2019). Analisis Faktor Kesadaran Literasi Keuangan Syariah Mahasiswa Keuangan dan Perbakan Syariah. Equilibrium, 7(1), 44-45.

Ningsih, S., \& Dukalang, H. H. (2019). Penerapan Metode Suksesif Interval pada Analsis Regresi Linier Berganda. Jambura Journal of Mathematics, 1(1), 46.

Nugroho, A. H. (2019). Analisis pengaruh psikologi investor pada Keputusan investasi saham (studi kasus seluruh investor yang terdaftar di Bursa Efek Indonesia). IImiah, 1.

Nurrohmah, R. F., \& Purbayati, R. (2020). Pengaruh Tingkat Literasi Keuangan Syariah dan Kepercayaan Masyarakat terhadap Minat Menabung di Bank Syariah. Jurnal Maps (Manajemen Perbankan Syariah), 3(2), 140-153.

Oktrima, B. (2017). Pengaruh Profitabilitas, Likuiditas, dan Struktur Modal terhadap Nilai Perusahaan. Sekuritas, 1(1), 98-107.

Otoritas jasa keuangan. (2013). Literasi Keuangan. Retrieved November 19, 2020, from https://www.ojk.go.id/id/kanal/edukasi-dan-perlindungan-konsumen/Pages/LiterasiKeuangan.aspx

Otoritas jasa keuangan. (2021). Saham Syariah. Retrieved from https://www.ojk.go.id/id/kanal/syariah/data-dan-statistik/sahamsyariah/Documents/Pages/-Statistik-Saham-Syariah---Februari-2021/Statistik Saham2021 Februari.pdf

Pajar, R. C., \& Pustikaningsih, A. (2017). Pengaruh Motivasi Investasi Dan Pengetahuan Investasi Terhadap Minat Investasi Di Pasar Modal Pada Mahasiswa Fe Uny. Profita, 1(2), 7.

Pandoyo, \& Sofyan, M. (2018). Metodologi Penelitian Keuangan dan Bisnis. Bogor: In Media.

Pangestika, T., \& Rusliati, E. (2019). Literasi dan efikasi keuangan terhadap minat mahasiswa berinvestasi di pasar modal. Jurnal Riset Bisnis Dan Manajemen, 12(1), 37-42. 
Etihad: Journal of Islamic Banking and Finance

Vol. 1, No. 2 Juli-Desember: 115-131

Pramana, I. B. A., \& Badera, I. D. N. (2017). Analisis Faktor-Faktor yang Mempengaruhi Risiko Investasi Saham. E-Jurnal Akuntansi Universitas Udayana, 18, 1860. Retrieved from

Priyatno, D. (2018a). SPSS Panduan Mudah Olah Data Bagi Mahasiswa \& Umum. (Giovanny, Ed.). Yogyakarta: ANDI.

Priyatno, D. (2018b). SPSS Panduan Mudah Olah Data Bagi Mahasiswa \& Umum. (Giovanny, Ed.). Yogyakarta: ANDI.

Putra, I. P. S., Ananingtiyas, H., Sari, D. R., Dewi, A. S., \& Silvy, M. (2016). Pengaruh Tingkat Literasi Keuangan, Experience Regret, dan Risk Tolerance pada Pemilihan Jenis Investasi. JBB, 5(2), 271-282.

Riski, T. R., \& Sulistianingsih, H. (2020). Literasi Keuangan, Media Sosial dan Perilaku Keuangan Mahasiswa Dikota Padang Tri. Ekonomi Dan Bisnis, 22(1), 175.

Riyanto, S., \& Hatmawan, A. A. (2020). Metode Riset Penelitian Kuantitatif Penelitian di Bidang Manajemen, Teknik, Pendidikan dan Eksperimen. Yogyakarta: Deepublish Publisher.

Rodoni, A., \& Fathoni, M. A. (2019). Manajemen Investasi Syariah. (A. Suslia, Ed.). Jakarta: Salemba Diniyah.

Salisa, N. R. (2020). Faktor yang Mempengaruhi Minat Investasi Di Pasar Modal : Pendekatan Theory Of Planned Behaviour ( TPB ). Jurnal Akuntansi Indonesia, 9(2), 182.

Saputra, M. N. A. (2016). Rekonstruksi Keputusan Ketua BAPEPAM dan Lembaga Keuangan Nomor: KEP-180/BL/2009 Tentang Kriteria dan Penerbitan Daftar Efek Syariah. Perbankan Syariah, 1(1), 49-59.

Saraswati, K. R. A., \& Wirakusuma, M. G. (2018). Pemahaman Atas Investasi Memoderasi Pengaruh Motivasi dan Risiko Investasi Pada Minat Berinvestasi. E-Jurnal Akuntansi, 24, 1586. p28

Sarwar, A., \& Afaf, G. (2016). A comparison between psychological and economic factors affecting individual investor's decision-making behavior. Cogent Business and Management, 3(1).

Sholikhah, A. (2016). Statistik Deskriptif Dalam Penelitian Kualitatif. KOMUNIKA: Jurnal Dakwah Dan Komunikasi, 10(2), 345.

Shulhan Fariqi. (2020). Pengaruh Motivasi Diri dan Literasi Keuangan terhadap Minat Investasi Dimediasi oleh Perkembangan Teknologi. Universitas Islam Negeri Maulana Malik Ibrahim.

Silaen, S. (2018). Metodologi Penelitian Sosial Untuk Penulisan Skripsi dan Tesis. Bogor: In Media. 
Etihad: Journal of Islamic Banking and Finance

Vol. 1, No. 2 Juli-Desember: 115-131

Sudirman, \& Alhudori, M. (2018). Pengaruh Konsumsi Rumah Tangga, Investasi Terhadap Pertumbuhan Ekonomi Di Provinsi Jambi. Fakultas Ekonomi Dan Bisnis, 2(1), 85.

Sudjana. (2002). Metode Statistika. Bandung: Tarsito.

Susanti, S., Hasan, M., Ahmad, M. I. S., \& Marhawati. (2018). Faktor-Faktor yang Mempengaruhi Minat Mahasiswa Berinvestasi di Galeri Investasi Universitas Negeri Makasar. Prosiding Seminar Nasional Pendidikan Ekonomi, 4.

Tandio, T., \& Widanaputra, A. A. G. P. (2016). Pengaruh Pelatihan Pasar Modal, Return, Persepsi, Risiko, Gender, dan Kemajuan Teknologi pada Minat Investasi Mahasiswa. EJurnal Akuntansi Universitas Udayana, 16(3), 2338.

Tanusdjaja, H. (2018). Keputusan Investasi investor Individu Berdasarkan Kompetensi, Overconvidence, dan Pendidikan. Muara Ilmu Ekonomi Dan Bisnis2, 2(1), 234-235.

Trenggana, A. F. M., \& Kuswardhana, R. (2017). Pengaruh informasi produk, risiko investasi, kepuasaan investor dan minat mahasiswa berinvestasi. Sekretaris \& Administrasi Bisnis, I(1), 15.

Watiningsih, F. (2018). Pengaruh Profitabilitas, Ukuran Perusahaan, dan Pertumbuhan terhadap Struktur Modal pada Perbankan yang Terdaftar di BEI Periode 2008-2016. Sekuritas, 1(4), 92-105.

Widyastuti, T., \& Andamari, B. G. (2013). Faktor Fundamental, Suku Bunga dan Nilai Tukar Rupiah terhadap Return Saham. Akuntansi Dan Auditing, 10(1), 13-28.

Zulaihati, S., Susanti, S., \& Widyastuti, U. (2020). Teachers ' financial literacy : Does it impact on financial behaviour? Management Science Lettersn, 10, 657. 